\title{
Editorial
}

\section{Lipid Rafts in Keratinocyte Biology and Pathology}

The concept of lipid rafts is relatively recent, but has already demonstrated a considerable impact in the understanding of normal and pathological cell function. The term "lipid raft" was coined in the beginning of 1990s as a result of the investigations of protein sorting into the vesicles budding from plasma membrane. The research on lipid rafts gained momentum after publication of a seminal review paper leaded by Kai Simons in Nature in 1997 [1]. This article has been cited in more than 4400 papers, which documented the importance of lipid rafts in the understanding of cellular biology and pathology.

Rafts are nanometer-scale domains in plasma membranes based on a molecular composition essentially enriched in cholesterol, saturated phospholipids and sphingolipids. One important feature of lipid rafts is their ability to selectively attract particular membrane proteins on the basis of lipid-protein associations. Once "trapped" in a raft, the protein demonstrates decreased mobility. Thus, the concept of rafts helps to understand why proteins exhibit variable mobilities in the plasma membrane and how nanocompartments enriched in certain proteins are formed in the membranes.

But what is the relevance of rafts for epidermal biology? We were the first to demonstrate that membranes of epidermal keratinocytes, both in the epidermis and in culture, are particularly enriched in lipid rafts [2] and that disturbance of these domains induces an altered cellular signalling in this cell type [3]. Several research groups followed this lead and confirmed the strategic importance of rafts in the regulation of keratinocyte biology. Articles in this volume summarize the current knowledge in this field. Our focus was to gather articles of interest for research dermatologists and to highlight the opportunities for translational research in dermatology. We have invited the leading investigators in the field whose contributions to this supplement will help to understand how the epidermal lipid rafts regulate growth factor signaling, cell proliferation, differentiation, apoptosis, or cellular reaction to ultraviolet radiation, and what is the importance of rafts in skin disorders such as bullous diseases, viral infection or cancer.

\section{REFERENCES}

[1] Simons K, Ikonen E. Functional rafts in cell membranes. Nature 1997; 387: 569-72.

[2] Gniadecki R, Christoffersen N, Wulf HC. Cholesterol-rich plasma membrane domains (lipid rafts) in keratinocytes: importance in the baseline and UVA-induced generation of reactive oxygen species. J Invest Dermatol 2002; 118: 582-8.

[3] Jans R, Atanasova G, Jadot M, Poumay Y. Cholesterol depletion upregulates involucrin expression in epidermal keratinocytes through activation of p38. J Invest Dermatol 2004; 123: 564-73.

\section{Yves Poumay}

(Co-Guest Editor)

Cell \& Tissue Laboratory, URPHYM

University of Namur (FUNDP)

61 , rue de Bruxelles

B-5000 Namur

Belgium

E-mail: yvesoumay@fundp.ac.be
Robert Gniadecki

(Co-Guest Editor)

Department of Dermatology

University of Copenhagen

Bispebjerg Hospital

Bispebjerg Bakke 23

2400 Copenhagen NV

Denmark

E-mail:rg01@bbh.regionh.dk

(C) Poumay and Gniadecki; Licensee Bentham Open.

This is an open access article licensed under the terms of the Creative Commons Attribution Non-Commercial License (http://creativecommons.org/licenses/by-nc/ 3.0/) which permits unrestricted, non-commercial use, distribution and reproduction in any medium, provided the work is properly cited. 